\title{
PERAWATAN INTERNAL BLEACHING MENGGUNAKAN TEKNIK WALKING BLEACH PADA GIGI INSISIF SENTRAL KANAN RAHANG ATAS (CASE REPORT)
}

\author{
Djuanda $\mathrm{R}^{1}$ \\ Fakultas Kedokteran Gigi, Universitas Kristen Maranatha, Bandung 40164, Indonesia \\ E-mail: rudy_djuanda@yahoo.com
}

\begin{abstract}
Tooth discoloration is defined as extrinsic or intrinsic staining based on localization and etiology, appearance, severity and adhesion to the tooth structure. Tooth discoloration is a cosmetic problem and the teeth whitening procedure is more conservative than the restorative method. Tooth discoloration, especially those treated endodontically is a matter of concern for patients and dentists. Among the various bleaching techniques, the technique of "walking bleach" with hydrogen peroxide stands out because of its superior aesthetic results with less side effects. This paper presents a case of tooth discoloration in non-vital teeth that was successfully bleached using the walking bleach method.
\end{abstract}

Key words: Discoloration; Walking bleach; Hydrogen peroxide

\section{Pendahuluan}

Gigi yang sudah melewati perawatan endodontik dengan perubahan warna intrinsik membutuhkan perawatan estetik untuk mendapatkan kembali karakteristik warna kromatik yang mirip dengan gigi sebelahnya, terutama dalam kasus pada gigi anterior atas. Gigi yang sudah nekrosis dan mengalami trauma lebih sering mengalami pewarnaan gigi secara intrinsik. Pewarnaan gigi intrinsik tidak dapat dikembalikan warnanya dengan metoda home bleaching atau in office bleaching yang keduanya merupakan prosedur bleaching eksternal. Prosedur perawatan gigi untuk kasus pewarnaan gigi secara intrinsik dilakukan dengan prosedur internal bleaching atau disebut juga teknik walking bleaching. ${ }^{1}$ Idealnya prosedur pemutihan gigi harus dilakukan secara efektif, cepat, tahan lama, dan meminimalkan menimbulkan risiko resorpsi eksternal. Pencapaian keberhasilan perawatan harus didukung oleh pengetahuan tentang keterbatasan dan kemungkinan efek yang tidak diinginkan terkait dengan pengobatan. Hidrogen peroksida merupakan suatu bahan yang sering digunakan dalam prosedur dalam prosedur internal bleaching, selain itu terdapat bahan lain seperti natrium perborate sangat larut dalam air dan karbamid peroksida. 


\section{Laporan Kasus}

Pasien laki-laki berumur 26 tahun datang ke Instalasi Spesialis Konservasi Gigi dengan keluhan gigi depan kanan atas terlihat berwarna lebih gelap dari gigi sebelahnya. Sepuluh tahun yang lalu pasien pernah terjatuh dari motor dan giginya pernah terasa sakit namun sakitnya kemudian hilang. Gigi tersebut sudah dilakukan perawatan saluran akar. Pasien menginginkan warna giginya sama dengan gigi sebelahnya. Pasien tidak memiliki riwayat penyakit sistemik.

\section{Pemeriksaan Obyektif}

Pemeriksaan ekstra oral terlihat wajah simetris, bibir tidak ada kelainan, kelenjar submandibula kiri dan kanan tidak teraba dan tidak sakit. Pemeriksaan intraoral terlihat mahkota gigi 11 warnanya lebih gelap dibandingkan dengan gigi sebelahnya. Kebersihan mulut sedang, tidak terdapat kelainan pada jaringan sekitar. Pemeriksaan tes perkusi menunjukan reaksi negatif, tes tekan negatif, palpasi negatif, mobiliti negatif, dan hubungan rahang kelas I Angle (Gambar 1).

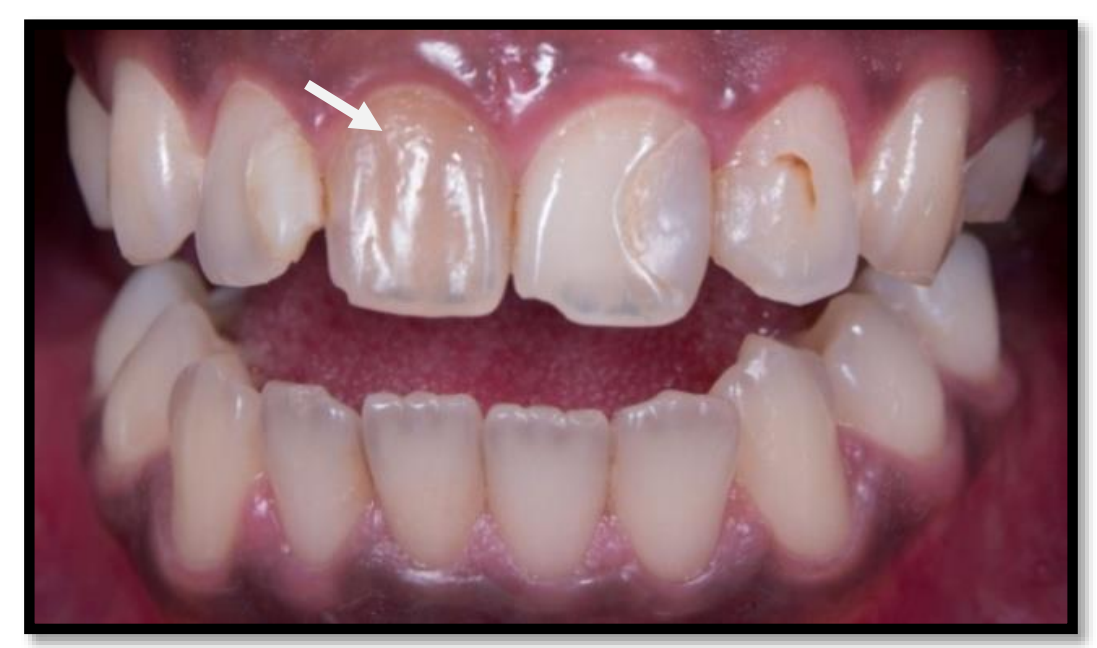

Gambar 1. Gambaran Klinis Gigi 11

\section{Pemeriksaan Radiografis}

Gambaran radiografis paska perawatan endodontik memperlihatkan gambaran radiopak dari mahkota sampai apeks memberikan kesan pengisian saluran akar yang hermetis. Membran periodontal dalam batas normal, lamina dura dalam batas normal, puncak tulang alveolar dalam batas normal dan tidak terlihat adanya kelainan pada periapikal. (Gambar 2). 


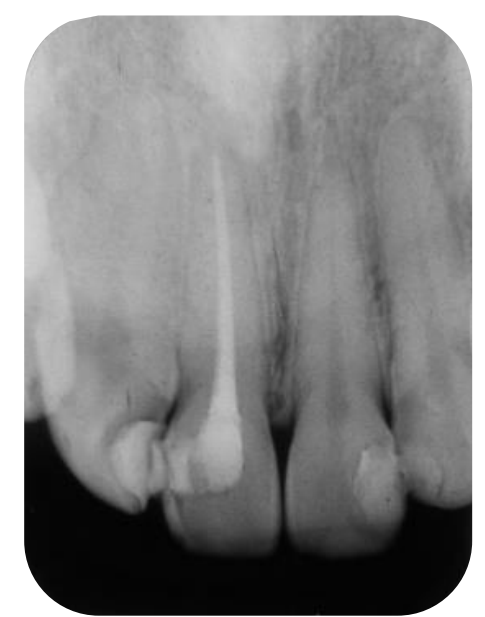

Gambar 2. Gambaran Radiografis Gigi 11

\section{Diagnosis}

Diagnosis gigi 11 adalah gigi non vital paska perawatan saluran akar disertai diskolorasi (previously treated tooth with normal apical tissues, AAE 2003).

\section{Rencana Perawatan}

Rencana perawatan yang akan dilakukan adalah internal bleaching dengan teknik walking bleach dilanjutkan dengan penambalan kelas I di palatinal menggunakan komposit secara direk.

\section{Tata Laksana Kasus}

\section{Kunjungan I}

Pada kunjungan pertama pasien diberikan penjelasan mengenai prosedur yang akan dilakukan. Biaya perawatan, efek samping yang dapat terjadi, kemungkinan hasil yang akan dicapai, kegagalan dan komplikasi tentang penggunaan bahan bleaching dipahami oleh pasien dan kemudian dilakukan penandatanganan informed consent.

Tahapan selanjutnya adalah pencatatan warna gigi sebelum dilakukan perawatan. Gigi tersebut sebelumnya dibersihkan dengan menggunakan rotary brush dan bubuk pumice untuk mendapatkan warna sebenarnya. Warna gigi dicocokan dengan menggunakan shade guide vitapan classical. Pada kasus ini warna awal adalah $\mathrm{C} 4$ (Gambar 3), dan warna yang ingin dicapai adalah warna A3 (Gambar 4). 


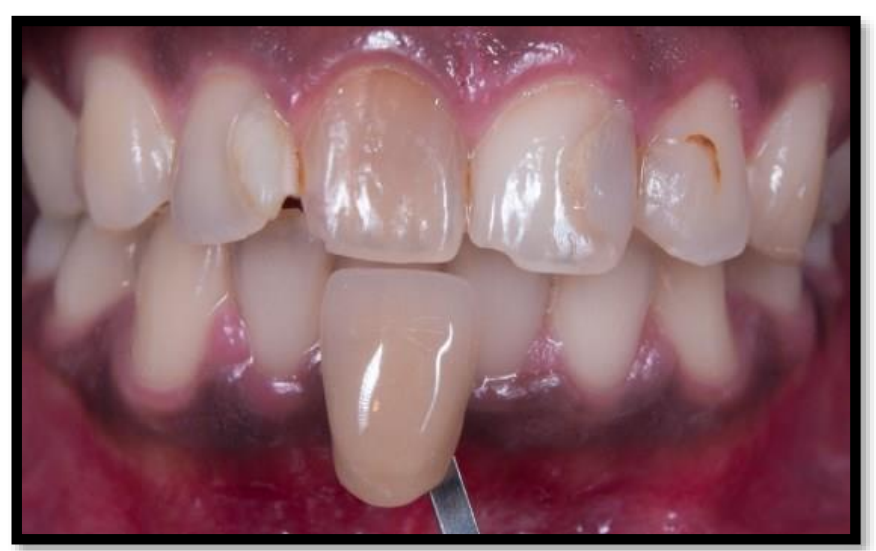

Gambar 3. Foto Pencatatan Warna Awal Gigi

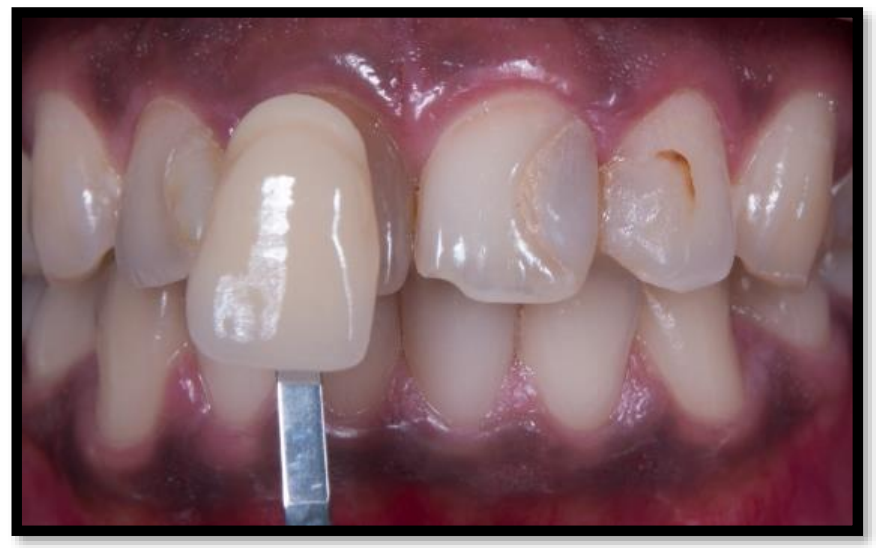

Gambar 4. Foto Warna Gigi yang Ingin Dicapai

Setelah didapatkan warna awal kemudian dilakukan pengukuran batas tepi insisal sampai CEJ dengan menggunakan probe periodontal pada bagian labial dan proksimal (Gambar 5).

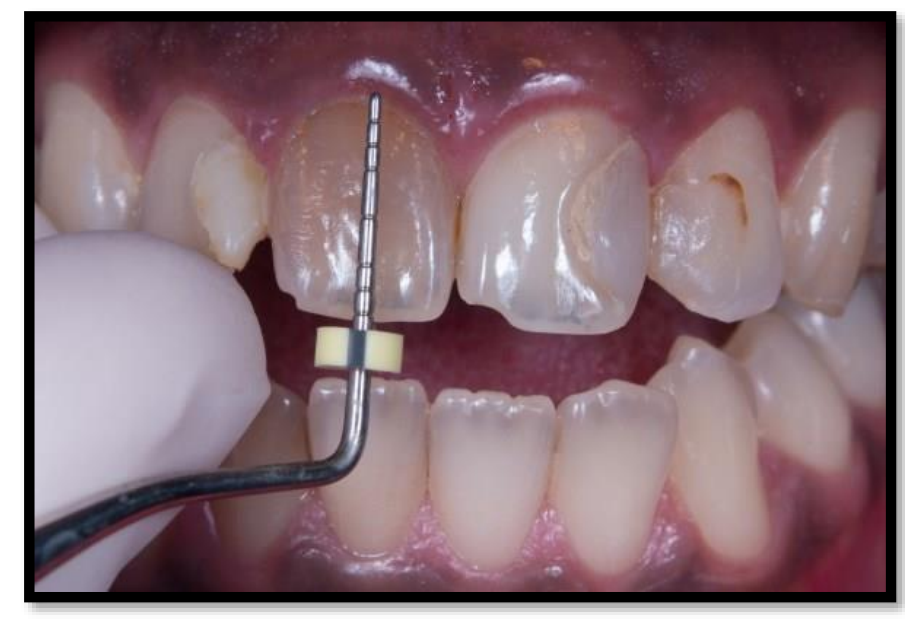

Gambar 5. Pengukuran Batas Tepi Insisal Sampai Servikal/CEJ 
Daerah kerja diisolasi dengan rubber dam dan dilakukan akses koronal dengan membuka kembali tambalan sementara dengan menggunakan bur bulat. Bahan pengisi saluran akar dikeluarkan sampai kedalaman $2 \mathrm{~mm}$ dibawah CEJ dengan menggunakan plugger panas yang telah diberi stop untuk memberikan tempat bagi bahan cervical seal. Kedalaman pengambilan bahan pengisi dikonfirmasi kembali menggunakan probe periodontal (Gambar 6).

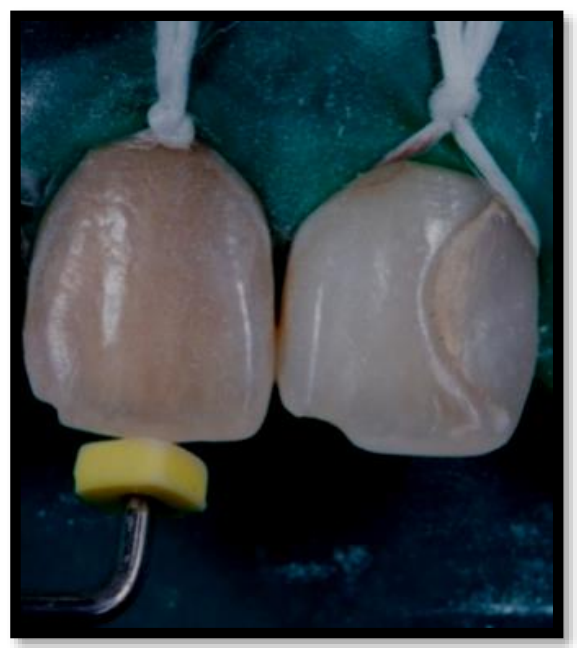

Gambar 6. Pengukuran Batas Pengambilan Bahan Pengisi Saluran Akar

Kavitas gigi 11 diirigasi dengan aquadest steril hingga bersih dan dikeringkan. Cervical seal dibuat dengan mengaplikasikan semen glass ionomer setebal $2 \mathrm{~mm}$ mengikuti outline garis servikal. Setelah cervical seal kering, bahan bleaching berupa gel hidrogen peroksida 35\% (Opalescence Endo, Ultradent Product Inc, USA) diaplikasikan pada bagian labial, kemudian kamar pulpa diberi cotton pellet serta ditutup dengan semen glass ionomer. Pasien diinstrusikan untuk kontrol 1 minggu kemudian. (Gambar 7)

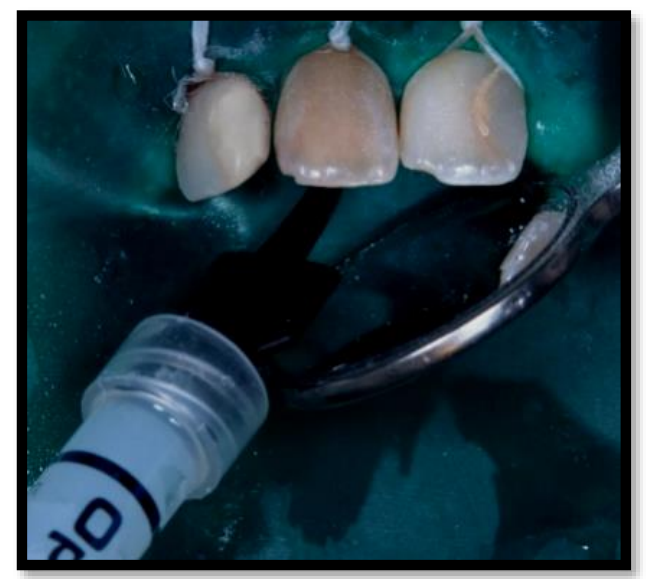

Gambar 7. Aplikasi Gel Hidrogen Peroksida 35\% 


\section{Kunjungan II}

Pada kunjungan kedua dilakukan pemeriksaan subjektif tidak ditemukan adanya keluhan pasien. Pemeriksaan objektif memperlihatkan perubahan warna gigi menjadi C3 (Vitapan Classical) (Gambar 8). Tambalan semen glass ionomer dibuka, kavitas dibersihkan dengan aquadest steril dan dikeringkan. Kemudian bahan bleaching diaplikasikan kembali bersama cotton pellet, selanjutnya kavitas ditutup dengan semen glass ionomer. Pasien diinstruksikan kontrol satu minggu kemudian.

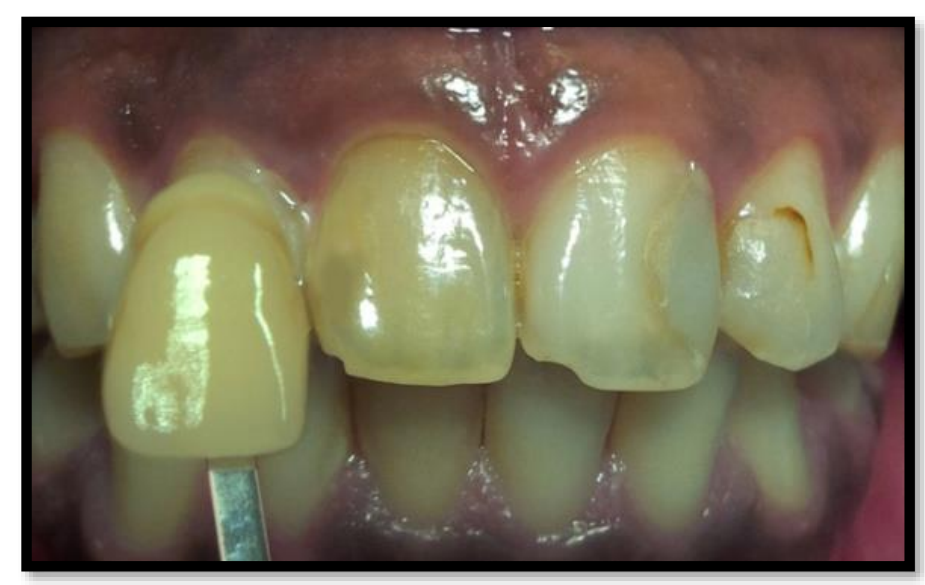

Gambar 8. Foto Klinis Kunjungan II

\section{Kunjungan III}

Pada kunjungan ketiga dilakukan pemeriksaan subjektif tidak ditemukan adanya keluhan pasien. Pemeriksaan objektif memperlihatkan perubahan warna gigi menjadi B3 (Vitapan Classical) (Gambar 9). Tambalan semen glass ionomer dibuka, kavitas dibersihkan dengan aquadest steril dan dikeringkan. Kemudian bahan bleaching diaplikasikan kembali bersama cotton pellet, selanjutnya kavitas ditutup dengan semen glass ionomer. Pasien diinstruksikan kontrol satu minggu kemudian.

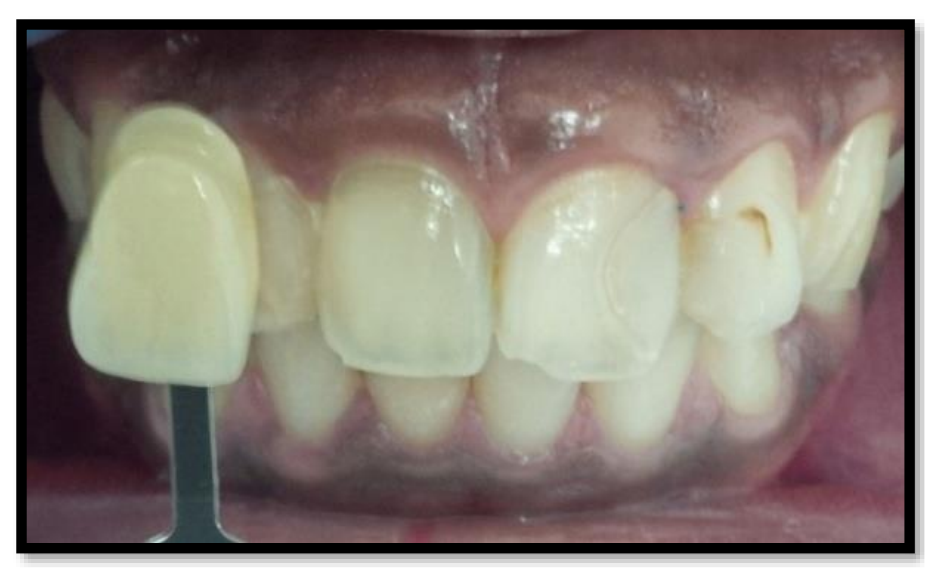

Gambar 9. Foto Klinis Kunjungan III 


\section{Kunjungan IV}

Pada kunjungan keempat dilakukan pemeriksaan subjektif tidak ditemukan adanya keluhan pasien. Pemeriksaan objektif memperlihatkan perubahan warna gigi menjadi A3 telah sesuai dengan warna gigi sebelahnya. Tambalan glass ionomer dibongkar, bahan bleaching dibuang dan kavitas diirigasi dengan aquadest steril. Kalsium hidroksida diaplikasikan ke dalam kavitas, kavitas ditutup kembali dengan cotton pellet serta tambalan glass ionomer.

\section{Kunjungan V}

Pada kunjungan kelima dilakukan pemeriksaan subjektif tidak ditemukan adanya keluhan pasien. Pemeriksaan obyektif menunjukkan respon negatif pada tes perkusi, tekan dan palpasi. Warna pada gigi 11 tidak mengalami perubahan, tetap berwarna A3. Semen glass ionomer dibuka dan kavitas dibersihkan dengan aquadest steril. Restorasi pada gigi 11 dilakukan dengan komposit secara direk, selain itu gigi 12, 21 dan 22 tambalan lamanya diganti (Gambar 10).

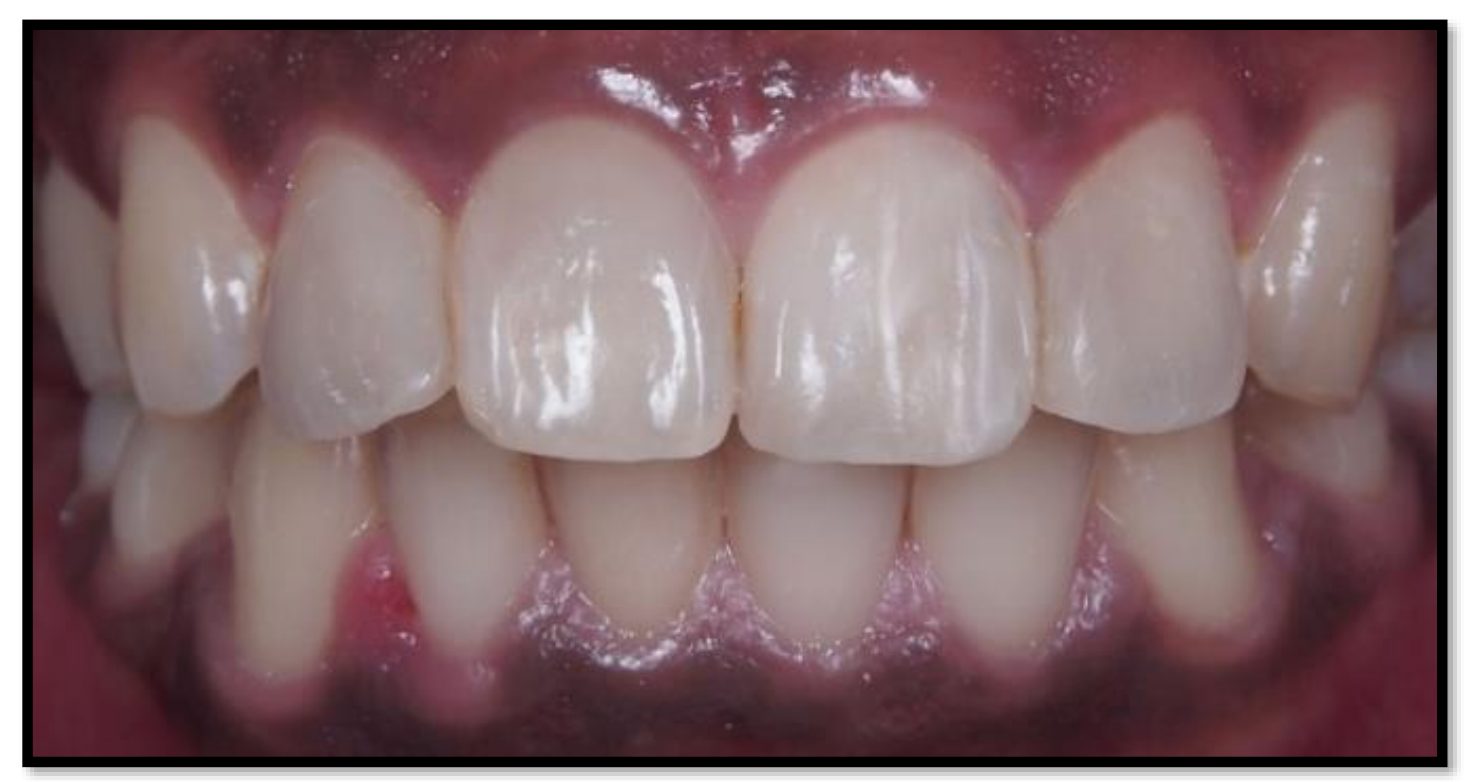

Gambar 10. Foto Klinis Kontrol

\section{Pembahasan}

Pewarnaan gigi khususnya pada bagian anterior, dapat mengganggu penampilan seseorang. Selain perawatan secara invasif, seperti pembuatan mahkota atau veneer, pemutihan gigi atau bleaching dapat menjadi suatu alternatif perawatan. Berlawanan dengan pembuatan mahkota atau veneer, bleaching gigi merupakan perawatan yang relatif non-invasif. Bleaching gigi yang telah dilakukan perawatan saluran akar sebelumnya dapat dilakukan dengan perawatan internal bleaching. ${ }^{1}$ 
Etiologi pewarnaan gigi dapat diklasifikasikan menjadi pewarnaan intrinsik, ekstrinsik, atau kombinasi keduanya, tergantung lokasi dan etiologinya. Pewarnaan intrinsik dapat terjadi melalui dua cara yaitu secara sistemik dan lokal. Secara sistemik dapat terjadi melalui drug-related (tetrasiklin), metabolik (dystrophic calcification, fluorosis), dan genetik (congenital erythropoietic porphyria, cystic fibrosis of the pancreas, hyperbilirubinemia, amelogenesis imperfecta, dan dentinogenesis imperfecta). Secara lokal dapat terjadi melalui nekrosis pulpa, perdarahan intrapulpa, sisa pulpa setelah perawatan endodontik, bahan endodontik, bahan pengisi koronal, resorpsi akar, dan proses aging. ${ }^{1,2}$

Diskolorasi gigi yang berhubungan dengan perawatan saluran akar disebabkan antara lain karena :

- Jaringan pulpa yang tersisa, jaringan pulpa yang tertinggal secara bertahap mengalami disintegrasi dan dapat menyebabkan diskolorasi. Tanduk pulpa harus diikutsertakan pada akses kavitas untuk meyakinkan pembuangan pulpa yang sempurna dan untuk mencegah retensi sealer pada tahap selanjutnya.

- Medikamen intrakanal, beberapa medikamen menyebabkan diskolorasi internal pada dentin. medikamen berbasis fenol atau iodoform pada saluran akar dan kamar pulpa yang berkontak langsung dengan dentin pada waktu lama dapat menyebabkan penetrasi dan oksidasi menyebabkan diskolorasi.

- Bahan pengisi saluran akar, yang sering menyebabkan diskolorasi parah. Kurangnya pembersihan bahan pengisi dan sealer pada kamar pulpa, terutama yang mengandung komponen metalik sering menyebabkan diskolorasi gelap. $2,3,4,5$

Diskolorasi juga dapat terjadi karena restorasi komposit. Kebocoran mikro disekitar restorasi menyebabkan staining. Margin yang terbuka menyebabkan bahan kimia masuk antara restorasi dan struktur gigi da mewarnai dentin dibawahnya. Komposit juga dapat mengalami diskolorasi seiring dengan waktu, yang akan mempengaruhi warna gigi. Kondisi ini diperbaiki dengan mengganti tambalan komposit lama dengan yang baru. ${ }^{2}$

Pada kasus ini perubahan warna pada gigi 11 disebabkan oleh faktor intrinsik. Nekrosis pada gigi 11 disebabkan oleh trauma yang terjadi sekitar 10 tahun yang lalu. Trauma pada gigi menyebabkan perdarahan intrapulpa dan lisis eritrosit. Darah atau komponen darah yang mengenangi kamar pulpa akan masuk ke dalam tubuli dentin secara difusi, sehingga terjadi perubahan warna pada mahkota gigi. Perubahan warna yang terjadi berkaitan dengan berapa lama pulpa telah menjadi nekrosis, semakin lama senyawa berwarna berada di dalam pulpa, semakin besar derajat perubahan warna. ${ }^{1}$

Bleaching merupakan alternatif perawatan yang lebih konservatif dibandingkan pembuatan mahkota maupun labial veneer pada gigi yang mengalami pewarnaan. Proses kimia dalam bleaching terjadi apabila bahan pemutih diaplikasikan ke gigi, biasanya menggunakan bahan oksidasi seperti hidrogen peroksida, klorin atau natrium hipoklorit. Meskipun proses bleaching merupakan proses kimia yang kompleks, prinsip medasar dari mayoritas proses bleaching adalah oksidasi tahap demi tahap dari pewarna dengan 
dekomposisi. Dalam kedokteran gigi, berdasarkan komponen oksidasi, bahan bleaching dapat dibagi menjadi dua kelompok: peroxide-based dan non-peroxide-based. ${ }^{6,7}$

Mekanisme bleaching masih belum jelas, berbeda berdasarkan tipe diskolorasi yang terlibat dan kondisi kimia dan fisik pada waktu reaksi. Karena memiliki berat molekul yang rendah, bahan ini dapat berpenetrasi ke dentin dan melepaskan oksigen yang memecahkan ikatan ganda komponen organik dan inorganik dalam dentin. Bahan bleaching merupakan oksidator, bereaksi pada struktur organik jaringan keras gigi, pigmen yang memiliki rantai panjang dengan perlahan terdegradasi menjadi molekul sederhana seperti karbondioksida, oksigen dan air yang memiliki warna lebih terang, molekul inorganik tidak dipecah, reksi reduksi-oksidasi yang terjadi pada prosed bleaching dikenal dengan reaksi redoks. Secara umum peroksida yang tidak stabil menjadi radikal bebas yang tidak stabil. Radikal bebas ini mengoksidasi molekul lain. ${ }^{2,5,6,7}$

Pada kasus ini digunakan bahan bleaching perixode-base. Hidrogen peroksida merupakan agen oksidasi yang kuat. Penggunaan hidrogen peroksida dengan konsentrasi tinggi harus berhati-hati karena bersifat tidak stabil secara termodinamik dan bisa meledak, karena itu harus diletakkan di lemari es dan disimpan pada wadah gelap. Bahan bleaching dapat diaplikasikan menggunakan instrumen plastis dan plugger dan harus diganti setiap 3-7 hari. Biasanya dibutuhkan 2-4 sesi bergantung intensitas diskolorasi. Pasien harus diingatkan untuk memperhatikan giginya setiap hari supaya tidak overbleach ${ }^{4,8}$ Ketika bahan ini berkontak dengan gigi, hidrogen peroksida akan lepas dan penetrasi ke permukaan email dan dentin karena berat molekul peroksida yang relatif rendah (30 g/mol). Molekul reaktif ini menyerang molekul kromofor berwarna gelap dan rantai panjang dan memecah molekul ini menjadi molekul yang lebih kecil, lebih tidak berwarna, dan lebih difus. ${ }^{10,11}$

Kesuksesan intrakoronal bleaching pada gigi yang telah dirawat endodontik bergantung pada etiologi, diagnosis yang tepat, dan pemilihan teknik bleaching yang sesuai. Teknik walking bleach dipilih karena memerlukan chair time yang singkat, lebih aman dan lebih nyaman bagi pasien. Indikasi internal bleaching pada gigi yang telah dirawat endodontik yaitu : diskolorasi pada kamr pulpa, diskolorasi dentin, diskolorasi yang tidak dapat hilang dengan ekstrakoronal bleaching. Kontraindikasi internal bleaching: diskolorasi superfisial, formasi email dengan defek, kehilangan dentin yang parah. ${ }^{2,7,9}$

Servikal seal/barrier yang digunakan yaitu glassionomer untuk menutupi obturasi endodontik. Ketinggian koronal menutup tubuli dentin dan sesuai dengan eksternal epitel attachment. Ketebalan barrier kurang lebih $2 \mathrm{~mm}$, dan terletak $1 \mathrm{~mm}$ di bawah CEJ. Proteksi ini dilakukan untuk mencegah terjadinya efek samping internal bleaching berupa resorbsi akar eksternal. Resorbsi terjadi karena bahan kimia berdifusi melalui tubuli dentin dan defek sementum yang tidak terlindungi. kebocoran yang terjadi bisa menyebabkan nekrosis sementum, inflamasi ligamen periodontal sehingga akhirnya terjadi resorbsi akar. Aplikasi bahan bleaching menyebabkan denaturasi protein dentin dengan bahan oksidasi dan $\mathrm{pH}$ asam yang menginduksi reaksi benda asing. $\mathrm{pH}$ bahan 
bleaching yang rendah bisa merusak jaringan karena lingkungan asam optimal untuk aktivitas osteoklas menghasilkan resorbsi akar. ${ }^{2,5,8,12}$

Pada kasus ini restorasi pasca bleaching menggunakan resin komposit. Peroksida yang tersisa dari bahan bleaching, terutama hidrogen peroksida dapat mempengaruhi kekuatan bonding komposit, sehingga disarankan menunggu beberapa hari setelah bleaching sebelum dilakukan restorasi komposit. Penempatan kalsium hidroksida pada kamar pulpa selama beberapa hari berguna untuk buffering keasaman yang disebabkan bahan bleaching. ${ }^{2,8}$

\section{Simpulan}

Penggunaan hidrogen peroksida $35 \%$ untuk perawatan internal bleaching pada gigi 11 memberikan hasil yang cukup baik.

\section{Saran}

Penggunaan hidrogen peroksida 35\% sebagai bahan internal bleaching harus sangat hati-hati karena bahan ini sangat reaktif terhadap jaringan.

\section{Referensi}

1. Plotino G, Buono L, Grande NM. Nonvital Tooth Bleaching: A Review of the Literature and Clinical Procedures. 2008. JOE 34: 394.

2. John II, Leif KB. Endodontics. $5^{\text {th }}$ ed. BC Decker Inc. 2002. p. 845- 860

3. William HL. Intracoronal Bleaching of Pulpless Discolored Lower Incisors. Interational Dentistry-African Edition. 1(3):32-43

4. Ibrahim U, Hakan K. Bleaching Discolored Devital Teeth with Using of New Agents. IOSR-JDMS. 2014.:13(3):79-82

5. Gianluca P et al. Nonvital Tooth Bleaching: A Review of the Literature and Clinical Procedures. JOE. 2008:34(4):394-407

6. Brigitte Z, Franziska J, Adrian L. Bleaching of Nonvital Teeth. Schweiz Monatsschr Zahnmed. 2010:120(4):306-313

7. Nikhil B. Cervical root resorption and non vital bleaching. Endodontology. 2013:25(2):106-111

8. Anuradha R, Manisha G. Walking Bleach-Still Relevant; A Review With-A Case Report. Indian Journal of Dental Sciences. 2009:1(2):32-37

9. Juliana NS et al. Surface morphology alterations in bovine dentine exposed to different bleaching agents. Braz J Oral Sci. 2009:8(1):25-9

10. Wang X. Structural Aspects of Bleaching and Fluoride Application on Dental Enamel. Hamburg: Universitat Hamburg; 2008. 26-9.

11. Zimmerli B, Jeger F, Lussi A. Bleaching of Nonvital Teeth: A Clinically Relevant Literature Review. 2010. Schweiz Monatsschr Zahmed. 120 (4). 310. 
SONDE (Sound of Dentistry) Vol 4 No 2

12. Benjamin MB et al. Colorimeter and Scannning Electron Microscopy Analysis of Teeth Submitted to Internal Bleaching. JOE. 2010:36(2):334-337 